\title{
c-Myc-deficient B lymphocytes are resistant to spontaneous and induced cell death
}

\author{
I Moreno de Alborán ${ }^{\star, 1,2}, \mathrm{E}$ Baena ${ }^{1}$ and C Martinez-A ${ }^{1}$ \\ 1 Department of Immunology and Oncology (DIO) (Pharmacia-CSIC), Centro \\ Nacional de Biotecnología (CNB-CSIC), Universidad Autonoma de Madrid, \\ Cantoblanco, Madrid 28049, Spain \\ 2 I Moreno de Alborán and E Baena contributed to this work equally \\ * Corresponding author: I Moreno de Alborán. Tel: + 34-91-585-4537; \\ Fax: + 34-91-372-0493; E-mail: imoreno@cnb.uam.es
}

Received 16.1.03; revised 12.6.03; accepted 23.7.03; published online 29.8.2003 Edited by SJ Martin

\begin{abstract}
C-myc gene is a member of the myc family of protooncogenes involved in proliferation, differentiation, and apoptosis. Overexpression of $c$-myc in fibroblasts causes apoptosis under low serum conditions in a process that requires the interaction of CD95 and CD95L on the surface. We have previously reported an in vivo conditional model to inactivate the c-myc gene in B lymphocytes. Here, we show that $C$-Myc-deficient primary $B$ lymphocytes are resistant to different apoptotic stimuli. Nonactivated c-Myc-deficient B cells are resistant to spontaneous cell death. Upon activation, c-Myc-deficient $B$ lymphocytes express normal surface levels of activation markers, and show resistance to staurosporine and CD95-induced cell death.

Cell Death and Differentiation (2004) 11, 61-68. doi:10.1038/ sj.cdd. 4401319

Published online 29 August 2003
\end{abstract}

Keywords: CD95; CD95L; c-myc; apoptosis; flox; Cre; staurosporine

Abbreviations: fl, floxed allele; $\triangle$, deleted allele; AICD, activation-induced cell death; bHLHZip, basic region/helixloop-helix/leucine zipper; GEP, green fluorescence protein

\section{Introduction}

Myc proteins are basic region/helix-loop-helix/leucine zipper (bHLHZip) transcription factors involved in cell proliferation, differentiation, and apoptosis. ${ }^{1-5}$ One of its members, c-Myc, is expressed from immature stages of B-cell differentiation, and is rapidly induced upon mitogenic stimulation. ${ }^{6-8}$

Overexpression of $c-m y c$ induces apoptosis in fibroblasts and myeloid cell lines in low serum conditions. ${ }^{1,2,9}$ More recently, Hueber et al. ${ }^{10}$ have shown that c-Myc-induced apoptosis in fibroblasts requires the interaction on the cell surface of CD95, a member of the TNF receptor family, and its ligand CD95L, triggering an apoptotic pathway that activates a set of cysteine proteases, called caspases, which lead to cell death. ${ }^{11}$ In T-cell hybridomas, anti-CD3-induced cell death is mediated by CD95 and CD95L, and is prevented by the inhibition of c-Myc expression. ${ }^{12-15}$ Moreover, inhibition of activation-induced cell death (AICD) by TGF $\beta$ correlates with downregulation of surface CD95L, a process mediated by $c$-myc in T-cell lines. ${ }^{16,17}$

In B lymphocytes, downmodulation of $c$-myc expression correlates with induction of apoptosis in B-cell lines. ${ }^{18-20}$ AntiCD40 stimulation of $B$ lymphocytes induces the surface expression of CD95 and makes them susceptible to cell death by this receptor. ${ }^{21-23}$ Furthermore, addition of interleukin 4 to anti-CD40-activated $B$ lymphocytes renders these cells more resistant to CD95-induced cell death. ${ }^{24}$

Inactivation of c-myc gene in the germ line results in embryonic lethality at day $9.5 .{ }^{24}$ We have previously reported the generation of a conditional in vivo model to study $c$-myc function in B lymphocytes. ${ }^{25}$ Now, we have bred $c-m y c^{\text {filft; }}$; $C D 19^{\text {cre }}$ with a ROSA26-EGFP 'reporter' mouse, in order to circumvent the problems associated with incomplete deletion of the c-myc gene, ${ }^{25-27}$ and extended our studies to characterize the role of $c-m y c$ in programmed cell death in primary B lymphocytes. Upon activation, c-Myc-deficient B lymphocytes express normal surface levels of activation markers, and are more resistant to CD95 and staurosporineinduced cell death. Finally, resistance to CD95-induced cell death correlates with lower levels of surface expression of CD95 and CD95L.

\section{Results}

\section{Generation of $c-m y c^{f l / f I}$; $C D 19^{c r e}$; egfp mice}

We have previously reported the generation of mouse model to study c-myc function in B lymphocytes. In this in vivo model, approximately $60-70 \%$ of splenic $B$ cells show deletion of the $c$-myc gene. ${ }^{25}$ Therefore, we designed a strategy to isolate cmyc-deleted B cells from a mixed population of deleted and nondeleted B cells from $c-m y c^{f / f t l} ; C D 19^{\text {cre }}$ mice. With this aim, we crossed $c-m y c^{f / f / f l} ; C D 19^{\text {cre }}$ mice with a 'knockin' reporter mouse expressing the green fluorescence protein (GFP) under the endogenous promoter of the rosa26 gene (egfp). ${ }^{26,27}$ Expression of Cre recombinase from the CD19 endogenous locus would lead to specific deletion of both $c$ myc locus and the stop codon inserted in the egfp gene in B lymphocytes. This strategy would potentially allow us to select and isolate c-Myc-deficient B cells that express GFP.

We found that approximately $40 \%$ of B220 + B cells $(13.9 \%$ of total splenocytes) also expressed GFP in homozygous c-myc ${ }^{\text {flffl; }} \quad C D 1$ cre $^{\text {; }}$ egfp mice (flffl mice from hereafter) (Figure 1a). To test whether expression of GFP correlated with c-myc deletion, we purified splenic B220 + GFP + B lymphocytes from homozygous $\mathrm{fl} / \mathrm{fl}$, and heterozygous $c-m y c^{+/ f t} ; C D 19^{\text {cre }}$; egfp mice $(+/ f l$ mice $)$ by cell sorting. PCR analysis of $c-m y c$ alleles of genomic DNA from sorted B220 + GFP + B lymphocytes from homozygous $\mathrm{fl} f \mathrm{fl}$ mice showed deletion of both $c$-myc alleles (fl 'floxed' 
nondeleted allele, $\triangle$ deleted allele) in all GFP-expressing cells, and therefore these $\mathrm{B}$ cells are $c-m y c^{\triangle / \triangle}$ (Figure 1a and b).

a
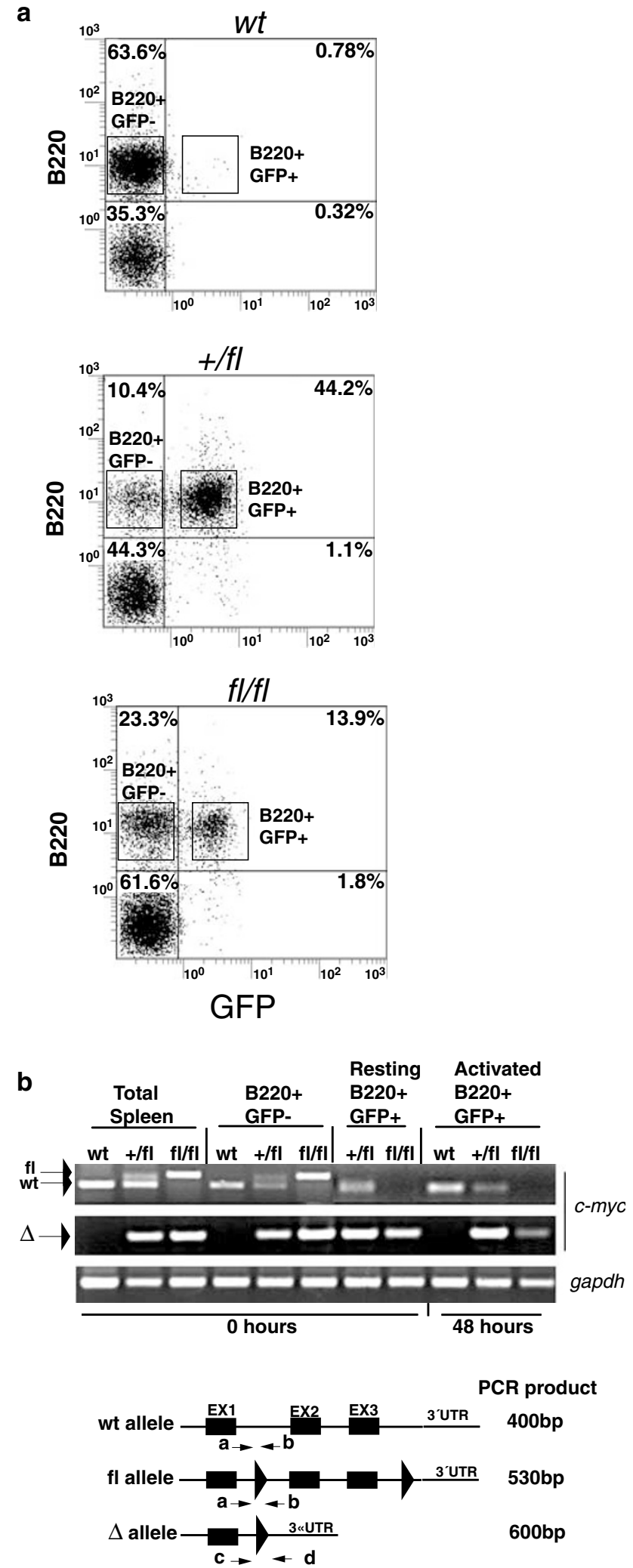

In heterozygous $+/ f /$ mice, we observed that $81 \%(44.2 \%$ of total splenocytes) of the B220 + cells expressed also GFP. This higher number of B220 + GFP + B cells in heterozygous mice might represent a proliferative advantage of cells carrying a wt allele of $c-m y c$, and it is consistent with our previous observations in $c-m y c^{+/ f l} ; C D 19^{c r e}$ mice. ${ }^{25}$ Genomic analysis by PCR of sorted B220 + GFP + B lymphocytes from heterozygous $+/ f l$ mice also revealed the deletion of the 'floxed' allele, and therefore these $\mathrm{B}$ cells are $c-m y c^{+/ \Delta}$ (Figure $1 \mathrm{a}$ and $\mathrm{b}, \triangle$ allele). Furthermore, PCR analysis of DNA from B220 + GFP + B cells from heterozygous $+/ f l$ and homozygous $\mathrm{fl} f \mathrm{fl}$ mice did not show the presence of 'floxed' alleles after $48 \mathrm{~h}$ of activation with anti-CD40 plus interleukin 4 (Figure 1b). Consequently, expression of GFP in B lymphocytes from heterozygous $+/ f l$ and homozygous $f / / f l$ mice correlates with deletion of the $c-m y c$ gene in these cells.

In contrast, PCR analysis of cell-sorted B220 + GFP - B cells from homozygous $\mathrm{fl} / \mathrm{fl}$ and heterozygous $+/ \mathrm{fl}$ mice revealed the presence of deleted ( $\triangle$ allele) and nondeleted alleles (floxed, fl) likely coming from $c$-myc-deleted and nondeleted cells that do not express GFP (Figure 1b).

Finally, thymidine incorporation experiments performed with sorted $\mathrm{B} 220+\mathrm{GFP}+\mathrm{B}$ lymphocytes did not reveal differences in cell proliferation capacity between $c-m y c^{+/ \triangle}$, $c-m y c^{+/+}(\mathrm{GFP}+)$, and $w t \mathrm{~B}$ cells. These results suggest that GFP expression in B lymphocytes did not interfere with cell proliferation (data not shown).

\section{C-Myc-deficient B lymphocytes are more resistant to CD95-, and staurosporine-induced cell death}

Hueber et al. showed that $c$-myc-induced apoptosis in fibroblasts required the interaction of CD95 and CD95L in a process that relies on the release of cytochrome $C$ from the mitochondria. ${ }^{10,28}$ Therefore, to determine whether the CD95 apoptotic pathway was affected in c-Myc-deficient B lymphocytes, we activated $\mathrm{B} 220+\mathrm{GFP}+c-m y c^{\triangle / \triangle}$ and $c-m y c^{+/ \triangle} \mathrm{B}$ lymphocytes with anti-CD40 antibody or anti-CD40 plus interleukin 4 for $48 \mathrm{~h}$ before inducing cell death with increasing concentrations of SCD95L.

At $48 \mathrm{~h}$ after activation with anti-CD40, we observed that $c-m y c^{\triangle / \triangle}$ B cells were more resistant to CD95-induced cell

Figure 1 B220 + GFP + B lymphocytes show deletion of the c-myc gene. (a) FACS analysis of splenocytes from wt, heterozygous + /fl $\left(c-m y c^{+\mid f l} ; C D 19^{\text {cre }}\right.$ egfp), and homozygous fl/fl (c-myc $c^{f / f I} ; C D 19^{\text {cre }} ;$ egfp) mice. Freshly isolated $B$ lymphocytes from spleen were stained with anti-B220 monoclonal antibody and purified by cell sorting (>95\% purity) using double-staining (B220 + GFP +) and/or single-staining (B220 + GFP-) gates. (b) PCR analysis of c-myc alleles of $B$ lymphocytes sorted as indicated in (a). At $0 \mathrm{~h}$, cell sorting and PCR analysis were performed on the B-cell populations indicated in (a), or unsorted total spleen was used from the different genotypes. B220 + GFP +, and B220 + GFP- B cells from heterozygous $+|f|$ and homozygous $f / f l$ mice, and B220 + GFP $-w t$ B lymphocytes were activated in vitro for $48 \mathrm{~h}$ with anti-CD 40 antibody $(10 \mu \mathrm{g} / \mathrm{ml})$ plus interleukin $4(20 \mathrm{ng} / \mathrm{ml})$ before harvesting the cells for PCR analysis $(40$ cycles) of the c-myc gene. PCR strategy to distinguish $c$-myc alleles is indicated below. (a, b) Primers amplify both wt and flox alleles. (c, d) Primers amplify only the deleted allele. Gapdh gene was used as control. Fl, nondeleted floxed allele; $\Delta$, deleted allele. All experiments are representative of three independent experiments. 
a

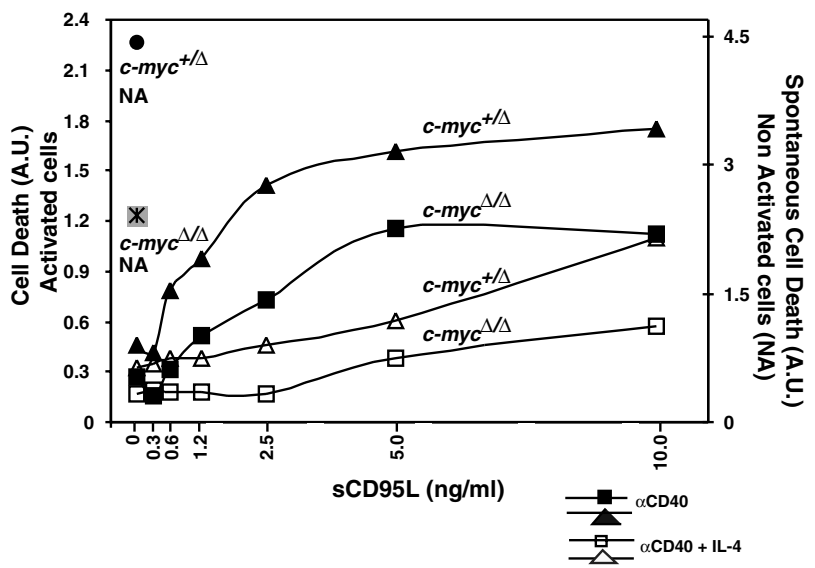

b Non-activated B cells Time in culture

$20 \mathrm{~h}$

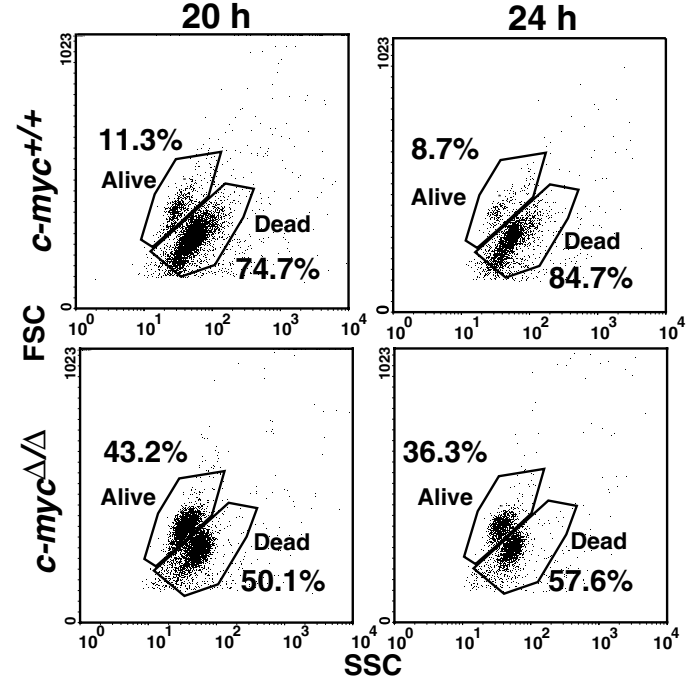

Figure 2 (a) C-Myc-deficient B lymphocytes are more resistant to CD95induced and spontaneous cell death. Sorted (B220 + GFP,$+>95 \%$ purity) $c$ $m y c^{\Delta / \Delta}$ and $c-m y c^{+/ \triangle} B$ lymphocytes from the spleens of homozygous $\mathrm{fll} f \mathrm{fl}$ and heterozygous $+/ f l$ mice were isolated. For CD95-induced cell death (left axis, activated cells, AU), cells were activated with $\alpha-C D 40$ antibody $(10 \mu \mathrm{g} / \mathrm{ml})$ or CD40 plus IL-4 $(20 \mathrm{ng} / \mathrm{ml})$ for $48 \mathrm{~h}$, before adding increasing concentrations of sCD95L. For spontaneous cell death (right axis, AU; nonactivated, NA), the same populations of cells were left untreated (no mitogenic stimulus) in normal medium. Cell death was monitored using Cell Death Detection ELISA (Roche). $\mathrm{AU}$, arbitrary units. Cells activated with -CD40 only. $\Delta, \boldsymbol{\Psi}$ Cells activated with $\alpha-\mathrm{CD} 40+\mathrm{IL}-4$. The experiment is representative of three independent experiments. (b) C-Myc-deficient $B$ lymphocytes are more resistant to spontaneous cell death. Sorted B lymphocytes were obtained as described in (a). Cells were put in medium without mitogenic stimulus, and analyzed by forward versus side scatter (FACS) to monitor cell death at the times indicated. The experiment is representative of three independent experiments

death than control $c-m y c^{+/ \triangle}$ B lymphocytes, upon treatment with SCD95L or anti-CD95 antibody (Figure 2a, Table 1).

The presence of interleukin 4 confers resistance to CD95induced cell death in CD40-stimulated primary B cells. ${ }^{29,30}$ We observed interleukin 4-dependent resistance to CD95induced cell death in $c-m y c^{+/ \triangle} \mathrm{B}$ lymphocytes (Figure 2a,
Table 1). In the case of $c-m y c^{\triangle / \triangle}$ B lymphocytes, we observed IL-4-dependent resistance, although less significant than control $c-m y c^{+/ \triangle}$ B lymphocytes. More importantly, treatment with SCD95L or anti-CD95 antibody still results in more resistance to cell death in $c-m y c^{\triangle / \triangle} B$ lymphocytes than heterozygous $c-m y c^{+/ \triangle}$ B lymphocytes (Figure $2 \mathrm{a}$, Table 1) after activation with anti-CD40 antibody or anti-CD40 plus interleukin 4. Consequently, this result suggests that the lack of the c-myc gene contributes to resistance to CD95-induced cell death independently of interleukin 4-mediated resistance. Interestingly, nonactivated C-Myc-deficient B cells are also more resistant to spontaneous cell death than nonactivated controls (Figure $2 a$ and $b$ ).

Staurosporine is a potent inhibitor of protein kinase $\mathrm{C}$ (PKC), that preferentially activates the mitochondrial apoptotic pathway. ${ }^{31}$ To test whether c-Myc-deficient B lymphocytes were also resistant to a different apoptotic stimuli, we treated them with staurosporine. Sorted B lymphocytes were activated with anti-CD40 antibody or anti-CD40 plus interleukin 4 and culture for $48 \mathrm{~h}$ before adding staurosporine. In Table 1, we observed that activated c-Myc-deficient B lymphocytes were more resistant to staurosporine-induced cell death than control B lymphocytes.

Finally, to test whether resistance to CD95-induced cell death in c-Myc-deficient B lymphocytes was due to a non-fully functional CD95L receptor, we performed a CD95L-mediated cytotoxic assay. ${ }^{32}$ In Figure 3 , we observed that activated $c-m y c^{\triangle / \triangle}$ B lymphocytes were capable of killing A20 target cells as well as control B lymphocytes (43.5 versus $44.0 \%$, respectively, for $20: 1 \mathrm{E}: \mathrm{T}$ ratio). Leakiness of cell tracker from A20 cells to primary B cells is unlikely since no $\mathrm{GFP}+\mathrm{CT}$-orange + (cell tracker) double-positive cells were present in the cultures (Figure $3 \mathrm{~b}$, data not shown). This result suggests that CD95L in c-Myc-deficient $B$ cells is functional to interact with CD95 and induce cell death through this receptor.

\section{c-Myc-deficient $B$ cells express low levels of surface CD95 upon stimulation with anti-CD40 or anti-CD40 plus interleukin 4}

We have previously reported that c-Myc-deficient B lymphocytes expressed normal levels of activation markers, and lower levels of CD95 and CD95L, upon stimulation with antiCD40 plus interleukin $4 .^{25}$ To find out whether $c-m y c^{\triangle / \triangle} B$ lymphocytes from $\mathrm{fl} / \mathrm{fl}$ mice express surface markers normally induced upon activation with anti-CD40 and anti-CD40 plus interleukin 4, we performed FACS analysis on cell-sorted $\mathrm{B} 220+$ cells.

In Figure $4 \mathrm{a}$ and $\mathrm{b}$, we show that $c-m y c^{\triangle / \triangle} \mathrm{B}$ lymphocytes express normal surface levels of CD25 and CD69 upon activation with anti-CD40 or anti-CD40 plus interleukin 4, when compared to $c-m y c^{+/ \triangle}$ B lymphocytes. However, we observed decreased CD95 surface expression in anti-CD40 and anti-CD40 plus interleukin 4-activated $c-m y c^{\triangle / \triangle} \mathrm{B}$ lymphocytes. In the case of CD95L, we detected a modest decrease in surface expression in $c-m y c^{\triangle / \triangle}$ B lymphocytes upon treatment with anti-CD40 plus interleukin 4 only. Different activation thresholds could account for differences in the surface expression of CD95L versus CD95 receptor. 
Table 1 c-Myc-deficient B cells are resistant to treatment with anti-CD95 antibody or staurosporine

\begin{tabular}{|c|c|c|c|c|c|c|}
\hline \multirow{2}{*}{$\begin{array}{l}\text { Sub G0/ } \\
\text { G1 (\%) }\end{array}$} & \multicolumn{3}{|c|}{$\alpha$ CD40 } & \multicolumn{3}{|c|}{$\alpha$ CD40 } \\
\hline & - & $+\alpha$ CD40 & + Staur & - & $+\alpha$ CD95 & +Staur \\
\hline $\begin{array}{l}\text { Exp 1 } \\
c-m y c^{+/ \Delta} \\
c-m y c^{\Delta / \Delta}\end{array}$ & $\begin{array}{l}15 \% \\
18 \%\end{array}$ & $\begin{array}{l}70 \% \\
43 \%\end{array}$ & $\begin{array}{l}\text { ND } \\
\text { ND }\end{array}$ & $\begin{array}{l}7.0 \% \\
7.1 \%\end{array}$ & $\begin{array}{l}35 \% \\
14 \%\end{array}$ & $\begin{array}{l}\text { ND } \\
\text { ND }\end{array}$ \\
\hline $\begin{array}{l}\text { Exp } 2 \\
c-m y c^{+/ \triangle} \\
c-m y c^{\triangle / \triangle}\end{array}$ & $\begin{array}{l}8.8 \% \\
8.6 \%\end{array}$ & $\begin{array}{l}70.8 \% \\
22.8 \%\end{array}$ & $\begin{array}{l}\text { ND } \\
\text { ND }\end{array}$ & $\begin{array}{l}6.5 \% \\
4.7 \%\end{array}$ & $\begin{array}{l}35.4 \% \\
17.5 \%\end{array}$ & $\begin{array}{l}\text { ND } \\
\text { ND }\end{array}$ \\
\hline $\begin{array}{l}\text { Exp } 3 \\
c-m y c^{+/ \triangle} \\
c-m y c^{\triangle / \triangle}\end{array}$ & $\begin{array}{c}11.6 \% \\
5.8 \%\end{array}$ & $\begin{array}{l}66.9 \% \\
41.1 \%\end{array}$ & $\begin{array}{l}\text { ND } \\
\text { ND }\end{array}$ & $\begin{array}{l}5.5 \% \\
5.5 \%\end{array}$ & $\begin{array}{l}28.8 \% \\
14.2 \%\end{array}$ & $\begin{array}{l}\text { ND } \\
\text { ND }\end{array}$ \\
\hline $\begin{array}{l}\text { Exp } 4 \\
c-m y c^{+/ \Delta} \\
c-m y c^{\Delta / \Delta}\end{array}$ & $\begin{array}{l}13.7 \% \\
5.4 \%\end{array}$ & $\begin{array}{l}68.1 \% \\
44.2 \%\end{array}$ & $\begin{array}{c}33.1 \% \\
7.1 \%\end{array}$ & $\begin{array}{l}9.1 \% \\
3.7 \%\end{array}$ & $\begin{array}{l}35.9 \% \\
15.6 \%\end{array}$ & $\begin{array}{c}26.1 \% \\
7.7 \%\end{array}$ \\
\hline $\begin{array}{l}\text { Exp } 5 \\
c-m y c^{+/ \triangle} \\
c-m y c^{\triangle / \triangle}\end{array}$ & $\begin{array}{l}12.3 \% \\
3.4 \%\end{array}$ & $\begin{array}{l}54.7 \% \\
30.8 \%\end{array}$ & $\begin{array}{l}33.6 \% \\
11.1 \%\end{array}$ & $\begin{array}{l}11 \% \\
1.2 \%\end{array}$ & $\begin{array}{l}35.3 \% \\
7.9 \%\end{array}$ & $\begin{array}{c}30.4 \% \\
3.5 \%\end{array}$ \\
\hline $\begin{array}{l}\text { Exp } 6 \\
c-m y c^{+/ \Delta} \\
c-m y c^{\Delta / \Delta}\end{array}$ & $\begin{array}{l}9.4 \% \\
6.6 \%\end{array}$ & & $\begin{array}{c}38.8 \% \\
9.5 \%\end{array}$ & $\begin{array}{l}9.8 \% \\
7.0 \%\end{array}$ & & $\begin{array}{c}25.5 \% \\
7.1 \%\end{array}$ \\
\hline
\end{tabular}

Same numbers of sorted B lymphocytes were activated with either anti-CD40 antibody (10 $\mu \mathrm{g} / \mathrm{ml})$ or anti-CD40 plus interleukin 4 (20 ng/ml). At $48 \mathrm{~h}$ after stimulation, cells were either treated with anti-CD95 antibody $(+\alpha \mathrm{CD} 95,100 \mathrm{ng} / \mathrm{ml}$, Jo2 Pharmigen) or staurosporine (+Staur, Sigma, $20 \mathrm{nM})$, or nontreated $(-)$. The table shows percentages of cell death (sub-G0/G1 values) by propidium iodide staining of six independent experiments. ND, not done

To characterize whether decreased surface expression of CD95 and CD95L correlated with changes in the transcriptional levels of these genes, we performed RT-PCR analysis on activated (B220 + GFP +) c-Myc-deficient $B$ lymphocytes. We did not detect any significant difference ( $<2$ fold) on the transcriptional levels of CD95 and CD95L between $c$-myc $c^{\triangle / \Delta}$ and $c$-myc ${ }^{+/ \Delta}$ B lymphocytes activated with anti-CD40 or anti-CD40 plus interleukin 4 (Figure 5a).

Resistance to CD95-induced cell death has been correlated with expression of the inhibitor of apoptosis c-Flip. C-Flip interacts with the adaptor protein FADD and the protease FLICE (caspase 8) inhibiting CD95-mediated cell death in lymphoid cells. ${ }^{33}$ Therefore, RT-PCR analysis was performed to see whether expression of $c$-flip gene was affected in c-Myc-deficient B lymphocytes. No differences in c-flip gene expression were (<two-fold) observed between c-Mycdeficient B lymphocytes and heterozygous controls (Figure 5a). We concluded from these experiments that c-Myc does not regulate c-flip, cd95, and cd95I gene expression in primary $B$ lymphocytes.

CD95 surface levels are reduced in $(B 220+\mathrm{GFP}+)$ $c-m y c^{\triangle / \triangle}$ B cells activated with anti-CD40 or anti-CD40 plus interleukin 4. Decreased surface expression of CD95 has been reported to confer resistance to CD95-induced cell death. ${ }^{34}$ Engagement of CD95 receptor on the surface leads to the activation of procaspase 8 , caspase $3,{ }^{35}$ and ultimately to cleavage of the caspase 3 substrate poly (ADP-ribose) polymerase (PARP). ${ }^{36}$ To determine whether higher resistance to anti-CD95-induced cell death in c-Myc-deficient cells correlated with changes in PARP processing, we performed Western blot analysis on these cells. In Figure 5b, we show that $c-m y c^{\triangle / \triangle}$ B lymphocytes have decreased PARP protein processing when compared with controls.

\section{Discussion}

We have previously reported the generation of a conditional mouse model to study $c-m y c$ function in B lymphocytes. In this previous model, analysis of $\mathrm{C}-\mathrm{Myc}$-deficient $\mathrm{B}$ cells was hampered by incomplete deletion of $c$-myc gene in all $B$ lymphocytes. Therefore, to overcome these problems, we bred $c-m y c^{f l / f l} ; C D 19^{c r e}$ mouse with a reporter mouse that expresses GFP upon cre-mediated deletion. In this report, we have shown that deletion of c-myc gene correlates with expression of GFP in B lymphocytes. We also observed c-myc-deleted cells in B lymphocytes that do not express GFP $(B 220+$ GFP - cells) (Figure 1a and b). We did not detect cells that express GFP and carry nondeleted $c$-myc alleles. Recently, Vooijs et al. ${ }^{37}$ have shown that Cre-mediated recombination is locus dependent. Consequently, lack of GFP expression in c-myc-deleted cells might be due to different accessibilities of the Cre recombinase to different loci (c-myc versus rosa26).

CD95/CD95L is induced in normal B cells following treatment with anti-CD40, leading to susceptibility to apoptosis via the CD95 pathway. ${ }^{21-23}$ Our results show that mitogenstimulated, c-Myc-deficient B lymphocytes are more resistant to CD95-induced cell death, and express low surface levels of CD95 and CD95L when compared to control cells (Figure $4 \mathrm{a}$ and b). Noteworthy is the fact that c-Myc-deficient $B$ cells express normal surface levels of activation markers like CD69 or CD25, showing that they are capable of receiving 
activation signals (Figure $4 a$ and b). One possibility is that reduced CD95 or CD95L surface expression could account for resistance to CD95-induced cell death, as previously reported in $\mathrm{T}$ cells. ${ }^{34}$ In addition, CD95 resistance is accompanied by decreased processing of PARP protein, which would be consistent with a lower activation of

a

E:T

20:1
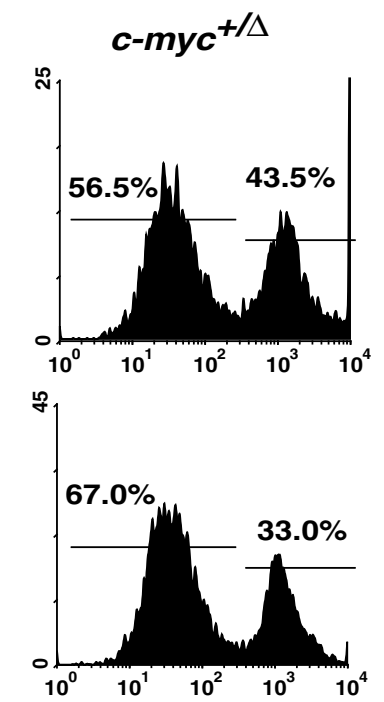

$5: 1$

2.5:1

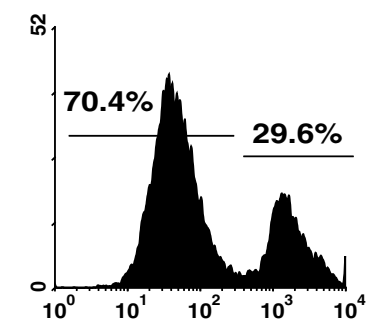

$0: 1$

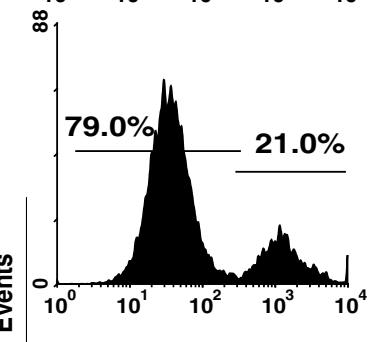

Annexin V

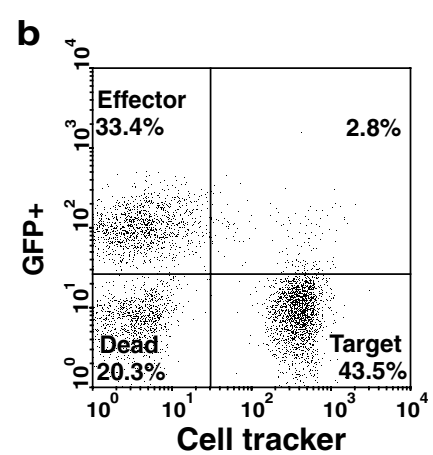

the CD95 apoptotic pathway in c-Myc-deficient B cells (Figure $5 \mathrm{~b}$ ). In contrast to cd95/ gene expression in T-cell hybridomas, ${ }^{16}$ we did not observe transcriptional regulation of cd95, cd95/ or c-flip genes by c-Myc in B lymphocytes (Figure 5a).

Taken together, our results cannot conclude whether decreased CD95/CD95L surface expression results from a direct role for $\mathrm{c}-\mathrm{Myc}$ in regulating the surface expression of these proteins, or is due to a defect in B-cell activation. In the context of a direct effect, we can speculate that c-Myc is affecting the surface expression of CD95, and to lesser extent $\mathrm{CD} 95 \mathrm{~L}$, by regulating the transport of these molecules to the membrane in B lymphocytes. However, c-Myc-deficient B cells also show resistance to staurosporine-induced cell death. This result would suggest a more general role of $c-m y c$ in sensitizing the cells to cell death to different apoptotic stimuli, rather than specifically regulating the surface expression of CD95 or CD95L. In addition, spontaneous cell death is reduced in c-Myc-deficient $B$ lymphocytes. This is particularly striking, since the levels of $c-M y c$ in resting $B$ cells are very low compared to activated $B$ lymphocytes. One possible explanation is that when deletion of c-myc gene occurs at any stage of $\mathrm{B}$-cell differentiation, the cell is already sensitized to apoptotic stimuli. In this context, a nonactivated c-Myc-deficient B lymphocyte would be more resistant that a wt B lymphocyte.

\section{Materials and Methods}

\section{Mice}

The generation of the $c-m y c^{f l f l l} C D 19^{c r e}$ mice has been described previously. ${ }^{25}$ Briefly, $c$-myc ${ }^{f / f f l}$ CD $19^{\text {cre }}$ mice were bred with ROSA26EGFP mice, ${ }^{26}$ and progeny bred to yield homozygous $c-m y c^{\text {fllfl }} ; C D 19^{\text {cre }}$; egfp mice (fl/ff) or heterozygous c-myc ${ }^{+/ f l} ; C D 19^{\text {cre }} ;$ egfp mice $(+/ f l)$. Mice were genotyped using a PCR-based analysis of tail genomic DNA.

\section{Genomic PCR and RT-PCR analysis}

Primers used to amplify floxed undeleted (flox, $530 \mathrm{bp}$ ) and deleted $(\triangle, 600$ bp) c-myc alleles were (a) TAAGAAGTTGCTATTTTGGC, (b) (TTTTCTTTCCGATTGCTGAC), (c) TCGCGCCCCTGAATTGCTAGGAA, and (d) TGCCCAGATAGGGAGCTGTGATACTT, respectively. Primers lac-Z1 GTGGTGGTTATGCCGATCG and lac-Z2 TACCACAGCGGAT GGTTCGG were used to amplify the ROSA26-EGFP allele. Gapdh gene was amplified using GAPDH5'CATCACCATCTTCCAGGAGC and GAPDH3'CATGAGTCCTTCCACGATACC primers. For RT-PCR analy-

Figure 3 (a) c-Myc-deficient B cells express functional CD95L. C-myc $c^{\triangle / \triangle}$ and $c-m y c^{+/ \triangle}$ B lymphocytes (effector cells isolated as described in Figure 2a) were activated with anti-CD40 antibody (see Materials and methods) for $48 \mathrm{~h}$. At this time, primary $B$ cells were incubated at different $E: T$ ratios with $A 20$ target $B$ cells. Cell tracker-positive cells (A20 cells) were selected by FACS and monitored for Annexin- $V$ staining. The experiment is representative of two independent experiments. (b) GFP + primary B cells (effector) do not incorporate cell tracker from A20 cells (target). FACS analysis of a mixed culture of GFP + primary B cells and A20 cells. GFP + B cells were sorted as described in Figure 2a. Subsequently, they were mixed with labeled (cell tracker, CT-orange) A20 cells, as described in Materials and methods. Dead cells correspond to primary $B$ cells only, since only GFP expression is lost after cell death (data not shown). The experiment is representative of three independent experiments 
a $\quad \cdots \cdots \cdots c-m y c^{\Delta / \Delta}-c-m y c^{+/ \Delta}$

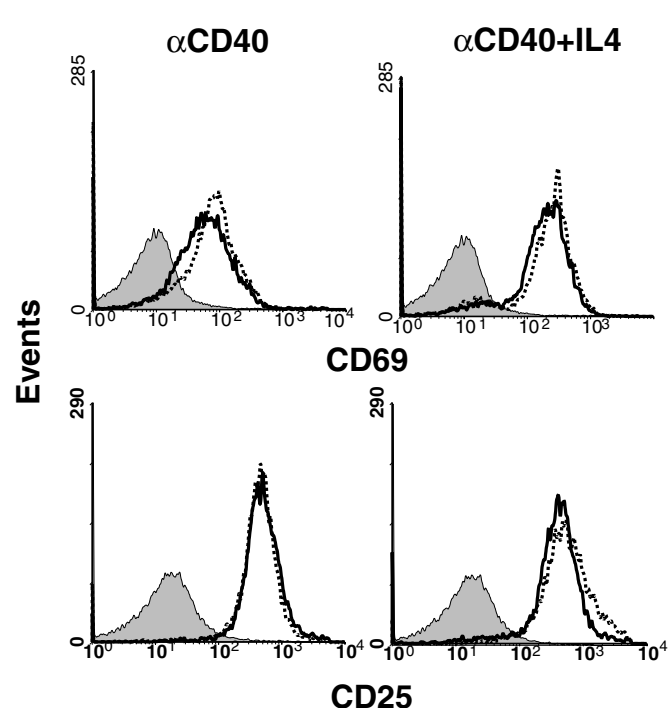

$\alpha \mathrm{CD40}$

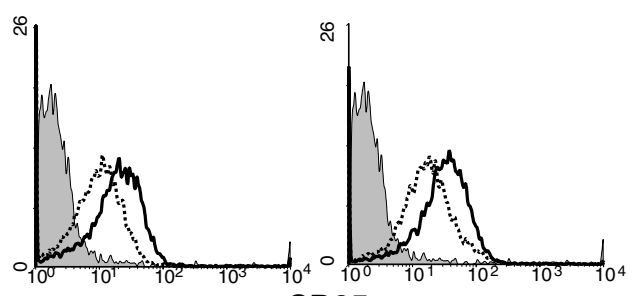

CD95
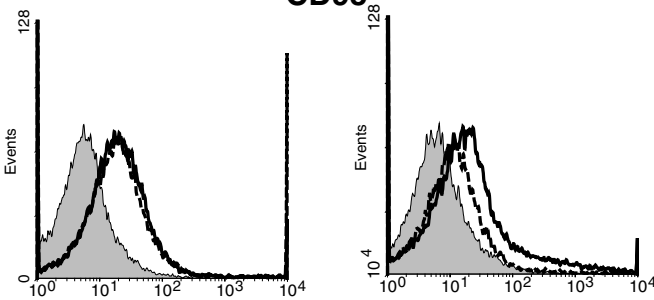

CD95L

b

\begin{tabular}{|c|c|c|c|c|c|c|c|c|c|}
\hline \multirow[b]{2}{*}{ 竎 } & \multirow[b]{2}{*}{$\begin{array}{l}c-m y c^{+/ \Delta} \\
c-m y c^{\Delta / \Delta}\end{array}$} & \multicolumn{2}{|c|}{ CD95 } & \multicolumn{2}{|c|}{ CD95L } & \multicolumn{2}{|c|}{ CD69 } & \multicolumn{2}{|c|}{ CD25 } \\
\hline & & $\begin{array}{c}M \\
7,28 \\
3,72\end{array}$ & $\begin{array}{l}\text { Pk } \\
2,10 \\
1,13\end{array}$ & $\begin{array}{l}M \\
6,75 \\
8,10\end{array}$ & $\begin{array}{c}\text { Pk } \\
2,08 \\
1,84\end{array}$ & $\begin{array}{l}M \\
110,0 \\
160,3\end{array}$ & $\begin{array}{c}\text { Pk } \\
1015 \\
1015\end{array}$ & $\begin{array}{l}M \\
83,9 \\
71,6\end{array}$ & $\begin{array}{l}\text { Pk } \\
1015 \\
1015\end{array}$ \\
\hline 웜 & $\begin{array}{l}c-m y c^{+/ \Delta} \\
c-m y c^{\Delta / \Delta}\end{array}$ & $\begin{array}{l}6,00 \\
5,54\end{array}$ & $\begin{array}{l}3,24 \\
1,76\end{array}$ & $\begin{array}{l}8,53 \\
5,09\end{array}$ & $\begin{array}{l}2,03 \\
0,87\end{array}$ & $\begin{array}{l}160,9 \\
237,5\end{array}$ & $\begin{array}{l}1015 \\
1015\end{array}$ & $\begin{array}{l}104,4 \\
74,9\end{array}$ & $\begin{array}{l}1015 \\
1015\end{array}$ \\
\hline
\end{tabular}

Figure 4 C-Myc-deficient B cells express lower levels of surface CD95 and CD95L upon activation with anti-CD40 or anti-CD40 plus interleukin 4. (a) Sorted $\mathrm{B} 220+\mathrm{GFP}+c-m y c^{\Delta / \Delta}$ and $c$-myc ${ }^{+/ \Delta}$ B lymphocytes (>95\% purity) were activated in vitro with anti-CD40 antibody or anti-CD40 plus interleukin 4 for $48 \mathrm{~h}$ before analysis by FACS. Negative isotypic controls are shown in gray. For CD95L staining, kay10 (Pharmigen) biotinylated antibody was used. The experiment is representative of three independent experiments. (b) Mean (M) and position peak (Pk) fluorescence values from (a)

sis, total RNA (DNAse treated) was used to synthesize the first strand of cDNA (Invitrogen) using random hexamers. The following primers were used for PCR. CD95 5' primer: TGAGCAGAAAGTCCAGCTGCT, CD95 3' a

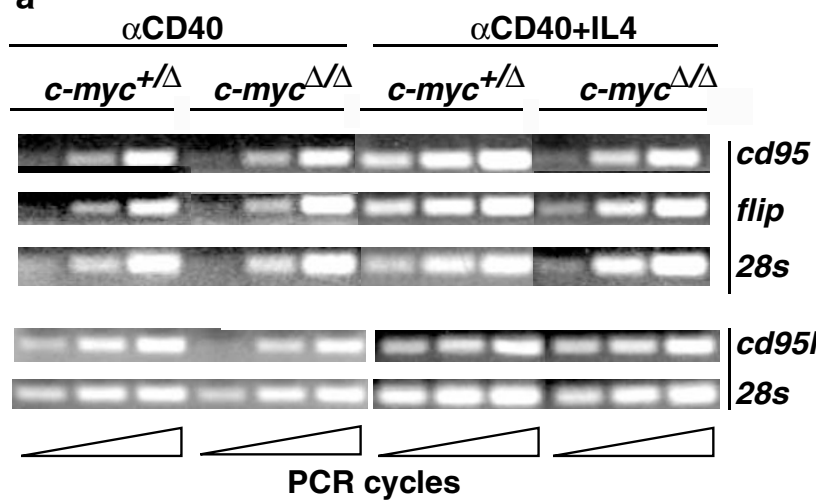

b

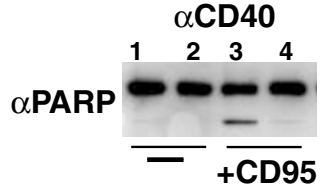

$\alpha$ CD40+IL4

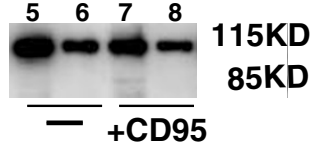

Figure 5 (a) c-Myc-deficient $B$ cells express normal levels of transcripts for cd95, cd95L, and c-flip. B220 + GFP $+c-m y c^{\Delta / \Delta}$ and $c-m y c^{+/ \Delta} \mathrm{B}$ lymphocytes were sorted by flow cytometry (>95\% purity), and activated either with anti-CD40 antibody or anti-CD40 plus interleukin 4. RT-PCR analysis of cd95, cd951, and c-flip transcripts was performed from these cells after $48 \mathrm{~h}$ in culture. $28 \mathrm{~S}$ was used as loading control. All PCR products were quantified using ImageQuant software, and showed less than two-fold difference. The experiment is representative of three independent experiments. (b) Western blot analysis of PARP protein from sorted B lymphocytes as in (a). The PARP-processed protein appears as an $85 \mathrm{kDa}$ band, and the unprocessed form as a $115 \mathrm{kDa}$ band. Cells were treated as in (a), and protein fractions were prepared 90 min after killing with anti-CD95 antibody 21 (j02, Pharmigen). C-myc ${ }^{\prime / \Delta \Delta \Delta}$ B cells, lanes 2-4-6-8. C-myc ${ }^{+/ \triangle}$ B lymphocytes, lanes 1-3-5-7. (-) No antibody. (+ CD95) antiCD95 antibody (Jo2, Pharmigen). The experiment is representative of two independent experiments

primer: TGCGACATTCGGCTTTTT, CD95L 5'primer: CAGGGAACCCCCACTCAAGCD95L, 3' primer: TGATCACAAGGCCACCTTTCT, c-flip 5' primer: AGCCTGGCCTGGAATCCATTA, c-flip $3^{\prime}$ primer:TGCAGAAAATGGAAGCCATGA, 28S $5^{\prime}$ primer:TGCCATGGTAATCCTGCT$\mathrm{CA}$, and $28 \mathrm{~S} 3^{\prime}$ primer:CCTCAGCCAAGCACATACACC. PCR reactions were carried out in the linear range. All Oligos were designed to yield $100-120$ bp PCR fragments.

\section{Cell sorting and cell culture conditions}

All experiments were done with purified B cells by cell sorting ( $>95 \%$ purity). Briefly, single-cell suspensions from spleens were stained with anti-B220 monoclonal antibody (Southern Biotechnology Association). Subsequently, B lymphocytes were sorted by flow cytometry (Coulter cell sorter), based on the surface expression of $\mathrm{B} 220+$ (wt cells) or $\mathrm{B} 220+\mathrm{GFP}+$ double-positive B cells $(+/ \Delta$ or $\Delta / \Delta$ cells $)$. After sorting, the purity was monitored by FACS, and was usually $>95 \%$ or more (data not shown). Sorted B lymphocytes $\left(10^{6} \mathrm{cells} / \mathrm{ml}\right)$ were cultured in RPMI (15\% FCS) with anti-CD40 antibody $\left(10 \mu \mathrm{g} / \mathrm{ml}\right.$, Pharmingen) and interleukin $4(20 \mathrm{ng} / \mathrm{ml}, \mathrm{RD})$ for $48 \mathrm{~h}$ at $37^{\circ} \mathrm{C}$. $B$ cells were either treated with anti-CD95 antibody $(21)(4 \mathrm{~h}, 100 \mathrm{ng} / \mathrm{ml}$, Jo-2 Pharmingen) or rhsCD95L (4h, Alexis Corp) or staurosporine ( $5 \mathrm{~h}$, Sigma $20 \mathrm{nM}$ ). 


\section{Antibodies and CD95L staining}

\section{Antibodies}

All antibodies for FACS are from Pharmingen. We used directly PEconjugated antibodies for CD95, CD25, CD69 and isotypic control PE antibodies. For CD95L staining, we used IgG2b, k-PE as isotypic control, FcBlock and biotinylated anti-CD95L (Kay 10). H11 antibody from Alexis corporation (clone H11) was also used to detect CD95L surface expression (data not shown). Streptavidin-PE was used with biotinylated antibodies (Southern Biotechnology).

\section{CD95L staining}

We followed the protocol described in Lundy and Boros. ${ }^{38}$ Briefly, B cells were first incubated $10 \mathrm{~min}$ at $4^{\circ} \mathrm{C}$ with $1 \mu \mathrm{l} /$ well of FcBlock (Pharmigen, $0.5 \mathrm{mg} / \mathrm{ml}$ ). After washing, biotinylated CD95L antibody (Kay 10, $0.5 \mu \mathrm{g} /$ well) or isotypic control $\left(0.5 \mu \mathrm{g} /\right.$ well) was added, and incubated at $4{ }^{\circ} \mathrm{C}$ for 30 min. After washing with PBS ( $2 \%$ FCS), streptavidin-PE was added, and incubated at $4{ }^{\circ} \mathrm{C}$ for $20 \mathrm{~min}$. Cells were resuspended in PBS $(2 \%$ FCS) and analyzed by FACS.

\section{Western Blotting}

Activated sorted B cells were harvested 90 min after anti-CD95 antibody was added. Protein extracts were prepared in a NP40 buffer $(50 \mathrm{mM}$ Tris$\mathrm{HCl}, \mathrm{pH}$ 7.5, $5 \mathrm{mM}$ EDTA, $150 \mathrm{mM} \mathrm{NaCl}$ and $1 \% \mathrm{NP}-40$ ) with protease inhibitors ( $1 \mathrm{mM}$ PMSF, $10 \mu \mathrm{g} / \mathrm{ml}$ aprotinin, $10 \mu \mathrm{g} / \mathrm{ml}$ leupeptin, $1 \mu \mathrm{g} / \mathrm{ml}$ pepstatin). Lysates were size-fractionated in $7 \%$ SDS-PAGE. Western blots were performed by standard methods, using a monoclonal antiPARP antibody (LABGEN) followed by HRP-conjugated anti-mouse IgG antibody (DAKO).

\section{Cell death detection}

Sorted cells were cultured as described above. Cell death was induced at $48 \mathrm{~h}$ postactivation by adding SCD95L kit (Alexis corporation), and monitored using Cell Death Detection ELISA plus (cat.\# 1774425, Roche). The assay is based on a quantitative sandwich-enzyme-immunoassay principle, using monoclonal antibodies directed against DNA and histones. This allows the specific determination of mono and oligonucleosomes in the cytoplasmatic fraction of cell lysates.

To monitor for cell death with anti-CD95 antibody or staurosporine (subG0/G1 fraction), the treated cells were permeabilized and stained with propidium iodide for $30 \mathrm{~min}$ at $37 \mathrm{~s} \mathrm{C}$ using DNA-Prep reagents kit (Beckman Coulter, cat.\#PN6607055) before analysis by FACS.

\section{Cytotoxicity assay}

A20 target cells described in Maleguine et al..$^{32}$ (murine B lymphoma cell line) were labeled with a cell tracker (CT-orange, Molecular Probes) to distinguish them from primary B lymphocytes. B cells were sorted from total spleen suspension based on GFP expression. Sorted GFP + $c-m y c^{\triangle / \triangle}$ and $c-m y c^{+/ \triangle}$ B lymphocytes were cultured as described above, at $10^{6} \mathrm{cell} / \mathrm{s} / \mathrm{ml}$. The effector cells (activated sorted B cells) were incubated with labeled target cells (CT-orange, Molecular Probes) $\left(10^{4}\right.$ A20 cells/well) at various $E: T$ ratios. The mixed cells were incubated at $37^{\circ} \mathrm{C}$ for $20 \mathrm{~h}$. Samples were stained with annexin-V (Immunotech), and analyzed by FACScan for the detection of apoptotic cells. A20 cells (dead and alive, data not shown) were $\mathrm{CT}$-orange + . Primary $B$ cells were
GFP + . Therefore, based on CT-orange expression, we distinguished A20 dead cells in the population of Annexin + cells.

\section{Acknowledgements}

We thank CMA's lab members for their input, and $X$ Mao and S Orkin for the EGFP reporter mice. IMA thanks FW Alt for his input and support. We are very grateful to all the staff of the animal facilities at CNB-CSIC for their help. IMA is supported by a Ramón y Cajal (RyC) fellowship, and EB by a predoc fellowship from the Spanish Ministry of Science and Technology. This work was supported by grants from the Ministry of Science and Technology and EU. The DIO was founded and is supported by the Spanish Council for Scientific Research (CSIC) and by PFIZER.

\section{References}

1. Askew DS, Ashmun RA, Simmons BC and Cleveland JL (1991) Constitutive $\mathrm{c}$-myc expression in an IL-3-dependent myeloid cell line suppresses cell cycle arrest and accelerates apoptosis. Oncogene 6: 1915-1922

2. Evan GI, Wyllie AH, Gilbert CS, Littlewood TD, Land H, Brooks M, Waters CM, Penn LZ and Hancock DC (1992) Induction of apoptosis in fibroblasts by c-myc protein. Cell 69: 119-128

3. Waters CM, Littlewood TD, Hancock DC, Moore JP and Evan GI (1991) c-myc protein expression in untransformed fibroblasts. Oncogene 6: 797-805

4. Facchini LM and LZ P (1998) The molecular role of Myc in growth and transformation: recent discoveries lead to new insights. FASEB J 12: 633-651

5. Dang CV (1999) C-Myc target genes involved in cell growth, apoptosis, and metabolism. Mol Cell Biol 19: 1-11

6. Zimmerman Ka and Alt FW (1990) Expression and function of myc family genes. Crit Rev Oncog 2: 75-95

7. Campisi J, Gray HE, Pardee AB, Dean M and Sonenshein GE (1984) Cell-cycle control of c-myc but not c-ras expression is lost following chemical transformation. Cell 36: 241-247

8. Kelly K, Cochran BH, Stiles CD and Leder P (1983) Cell-specific regulation of the $\mathrm{c}$-myc gene by lymphocyte mitogens and platelet-derived growth factor. Cell 35 (Part 2): 603-610

9. Thompson EB (1998) The many roles of c-Myc in apoptosis. Annu Rev Physiol 60: $575-600$

10. Hueber AO, Zornig M, Lyon D, Suda T, Nagata S and Evan Gl (1997) Requirement for the CD95 receptor-ligand pathway in c-Myc-induced apoptosis. Science 278: 1305-1309

11. Krammer PH (2000) CD95's deadly mission in the immune system. Nature 407: 789-795

12. Shi Y, Glynn JM, Guilbert LJ, Cotter TG, Bissonnette RP and Green DR (1992) Role for c-myc in activation-induced apoptotic cell death in T cell hybridomas. Science 257: 212-214

13. Brunner T, Mogil RJ, LaFace D, Yoo NJ, Mahboubi A, Echeverri F, Martin SJ, Force WR L, DH WC and DR G (1995) Cell-autonomous Fas (CD95)/Fasligand interaction mediates activation-induced apoptosis in T-cell hybridomas. Nature 373: 441-444

14. Dhein J, Walczak H, Baumler C, Debatin KM and PH K (1995) Autocrine T-cell suicide mediated by APO-1/. Nature 373: 438-441

15. Ju ST, Panka DJ, Cui $H$, Ettinger R, el-Khatib M, Sherr DH, Stanger BZ and Marshak-Rothstein A (1995) Fas(CD95)/FasL interactions required for programmed cell death after T-cell activation. Nature 373: 444-448

16. Genestier L, Kasibhatla S, Brunner T and Green DR (1999) Transforming growth factor beta1 inhibits fas ligand expression and subsequent activationinduced cell death in T cells via downregulation of c-Myc (in process citation). J Exp Med 189: 231-239

17. Brunner T, Kasibhatla S, Pinkoski MJ, Frutschi C, Yoo NJ, Echeverri F, Mahboubi A and Green DR (2000) Expression of Fas ligand in activated T cells is regulated by c-Myc. J Biol Chem 275: $9767-9772$

18. Sonenshein GE (1997) Down-modulation of c-myc expression induces apoptosis of B lymphocyte models of tolerance via clonal deletion. J Immunol 158: 1994-1997 
19. Wu M, Arsura M, Bellas RE, FitzGerald MJ, Lee H, Schauer SL, Sherr DH and Sonenshein GE (1996) Inhibition of c-myc expression induces apoptosis of WEHI 231 murine B cells. Mol Cell Biol 16: 5015-5025

20. DeFranco AL, Mittelstadt PR, Blum JH, Stevens TL, Law DA, Chan VW, Foy SP, Datta SK and Matsuuchi L (1994) Mechanism of B cell antigen receptor function: transmembrane signaling and triggering of apoptosis. Adv Exp Med Biol 365: 9-22

21. Rathmell JC, Townsend SE, Xu JC, Flavell RA and CC G (1996) Expansion or elimination of $B$ cells in vivo: dual roles for CD40- and Fas (CD95)-ligands modulated by the $B$ cell antigen receptor. Cell 87: 319-329

22. Rathmell JC, Cooke MP, Ho WY, Grein J, Townsend SE, Davis MM and Goodnow CC (1995) CD95 (Fas)-dependent elimination of self-reactive B cells upon interaction with CD4+ T cells. Nature 376: 181-184

23. Rothstein TL, Wang JK, Panka DJ, Foote LC, Wang Z, Stanger B, Cui H, Ju ST and Marshak-Rothstein A (1995) Protection against Fas-dependent Th1mediated apoptosis by antigen receptor. Nature 374: 163-165

24. Davis AC, Wims M, Spotts GD, Hann SR and Bradley A (1993) A null c-myc mutation causes lethality before 10.5 days of gestation in homozygotes and reduced fertility in heterozygous female mice. Genes Dev 7: 671-682

25. de Alboran IM, O'Hagan RC, Gartner F, Malynn B, Davidson L, Rickert R, Rajewsky K, DePinho RA and Alt FW (2001) Analysis of C-MYC function in normal cells via conditional gene-targeted mutation. Immunity 14: 45-55

26. Mao X, Fujiwara Y, Chapdelaine A, Yang H and Orkin SH (2001) Activation of EGFP expression by Cre-mediated excision in a new ROSA26 reporter mouse strain. Blood 97: 324-326

27. Friedrich $G$ and Soriano $P$ (1991) Promoter traps in embryonic stem cells: a genetic screen to identify and mutate developmental genes in mice. Genes Dev 5: $1513-1523$

28. Juin P, Hueber AO, Littlewood $T$ and Evan G (1999) c-Myc-induced sensitization to apoptosis is mediated through cytochrome $c$ release. Genes Dev 13: 1367-1381
29. Foote LC, Howard RG, Marshak-Rothstein A and Rothstein TL (1996) IL-4 induces Fas resistance in B cells. J Immunol 157: 2749-2753

30. Foote LC, Marshak-Rothstein A and Rothstein TL (1998) Tolerant B lymphocytes acquire resistance to Fas-mediated apoptosis after treatment with interleukin 4 but not after treatment with specific antigen unless a surface immunoglobulin threshold is exceeded. J Exp Med 187: 847-853

31. Tamaoki T, Nomoto H, Takahashi I, Kato Y, Morimoto M and Tomita F (1986) Staurosporine, a potent inhibitor of phospholipid/Ca++ dependent protein kinase. Biochem Biophys Res Commun 135: 397-402

32. Malyguine A, Derby E, Brooks A, Reddy V, Baseler M and Sayers T (2002) Study of diverse mechanisms of cell-mediated cytotoxicity in gene-targeted mice using flow cytometric cytotoxicity assay. Immunol Lett 83: 55-59

33. Irmler M, Thome M, Hahne M, Schneider P, Hofmann K, Steiner V, Bodmer JL, Schroter M, Burns K, Mattmann C, Rimoldi D, French LE and Tschopp J (1997) Inhibition of death receptor signals by cellular FLIP. Nature 388: 190-195

34. Delneste Y, Jeannin P, Sebille E, Aubry JP and Bonnefoy JY (1996) Thiols prevent Fas (CD95)-mediated T cell apoptosis by down-regulating membrane Fas expression. Eur J Immunol 26: 2981-2988

35. Los M, Van de Craen M, Penning LC, Schenk H, Westendorp M, Baeuerle PA, Droge W, Krammer PH, Fiers W and Schulze-Osthoff K (1995) Requirement of an ICE/CED-3 protease for Fas/APO-1-mediated apoptosis. Nature 375: 81-83

36. Lazebnik YA, Kaufmann SH, Desnoyers S, Poirier GG and Earnshaw WC (1994) Cleavage of poly(ADP-ribose) polymerase by a proteinase with properties like ICE. Nature 371 : 346-347

37. Vooijs $\mathrm{M}$, Jonkers $\mathrm{J}$ and Berns $\mathrm{A}$ (2001) A highly efficient ligand-regulated $\mathrm{Cre}$ recombinase mouse line shows that LoxP recombination is position dependent. EMBO Rep 2: 292-297

38. Lundy SK and Boros DL (2002) Fas ligand-expressing B-1a lymphocytes mediate CD4(+)-T-cell apoptosis during schistosomal infection: induction by interleukin 4 (IL-4) and IL-10. Infect Immun 70: 812-819 